\title{
INTENSIVE CARE OF THE PUERPERIUM (ICP) IMPACT ON THE POSTPARTUM SELF-CAREABILITY IN WONOKROMO
}

\author{
Yunik Windarti ${ }^{1}$, Uke Maharani Dewi ${ }^{2)}$ \\ Email: yunikwinda@unusa.ac.id \\ ${ }^{1,2}$ Universitas Nahdlatul Ulama Surabaya \\ Jln Smea No 57 Surabaya 60243, Indonesia Telp (031) 8291920
}

Article Information

Received:

July 24,2019

Revised:

December 23, 2019

Accepted:

January 19, 2020

Available online:

January 23,2020

\begin{abstract}
Health monitoring since pregnancy to puerperium is crucial to do to avoid complications. Monitoring during the puerperium period still lacked, especially when the mother has returned home. Many complications occur during the puerperium, such as healing of perineal tears, uterine subinvolution, psychological factors, breastfeeding problems (blocked duct, engorgement, mastitis), and not few found death due to bleeding and infection. Special attention and debriefing for postpartum mothers were needed to prepare mothers to be more independent in caring for themselves. The purpose of this study was to analyze intensive care of the puerperium (ICP) effect on postpartum self-care capability. Method of this study was Quasi-experimental research with a quantitative study combination approach (experimental group) on ICP and qualitative methods (interviews) on postpartum self-care. The population of this study were postpartum maternal taken as the sample using nonprobability sampling technique with incidental sampling for three months in Wonokromo Sub-district, Surabaya. The data were analyzed using the chi-square test. The results showed from 37 respondents who received ICP, $62.16 \%$ of respondents were able to carry out postpartum self-care properly. Furthermore, from 37 respondents who did not receive ICP, $70.27 \%$ of respondents found lacking to carry out postpartum selfcare. The $p$-value $=0.005<p=0.05$ means that there was an influence of ICP on postpartum self-care ability.
\end{abstract}

Keywords: Intensive care of the puerperium, Self-care

\section{Introduction}

Indonesian people's custom believes that when a mother who has given birth, there will not be any complication, so their focus was only on the baby. Whereas maternal mortality rate during puerperal was high and should not be ignored. Survey Penduduk Antar Sensus (SUPAS) showed that in 2015 maternal mortality reached 305 maternal deaths per 100,000 live births. ${ }^{[1]}$ The death of women of childbearing age in poor countries was estimated to be around 25-50\% which was the cause of health, childbirth, and postpartum problems. ${ }^{[2]}$ Maternal mortality often occurs in the puerperium because postpartum self-care was not optimal. Therefore the puerperal period becomes prone to death. ${ }^{[3]}$ Based on the data and people's habits on postpartum self-care, it is necessary to strive for a postpartum mother to be able to perform postpartum self-care optimally at home; although the role of health workers, family, and the environment was also a necessary factor in undergoing the puerperium. 
Various attempts were made to optimized postpartum self-care at home have been carried out in several studies. Most of the postpartum mothers perform postpartum self-care regularly after receiving a short message service (SMS) sent by health workers to remind them to continue their self-care at home. ${ }^{[4]}$ Counselling and demonstration given by nurses at hospital about postpartum selfcare were about perineal care, breast care, nutrition and hydration, resting, ambulation, kegel and also breastfeed. ${ }^{[5]}$ Health workers also need to monitor during the puerperium period because if they did not, could cause postpartum mothers to experience more problems which could become a complication. Postpartum care according to the standard is service for postpartum mothers at least three times; at six hours postpartum until the third day, on the second week, and on the sixth week including giving vitamin A twice and the preparation and use of contraceptives. ${ }^{[6]}$ This period was where the role of health workers to provide intensive care of the puerperium (ICP) during the puerperium. Intensive care of the puerperium (ICP) defines as care that is carried out for postpartum mothers since their stay at health care until they were at home by involving families that are done intensively to support their recovery. ICP begins when entering the puerperium period (after 2 hours postpartum) to 10 days postpartum; begins with early mobilization, puerperal counselling, head relaxation massage, oxytocin massage, breast care, correct breastfeeding techniques, breast excercise, and postpartum excercise.

Postpartum mothers being educated about danger signs, elimination, personal hygiene, rest, adequacy of nutrients and fluids and breastfeeding. The counselling aimed to improve health status, reducing the risk of infection, providing comfort, and improving personal hygiene that was lacking. When mother lack of sleep, it could affect in various ways like decreases of breast milk produce, slowing the process of uterine involution, bleeding, and also depression. Adequacy in nutrients and fluids being given because, during the puerperal period, the mother needs a variety of nutritious foods to restore their strength. Health education for postpartum mothers in breastfeeding is beneficial because breastfeeding is a way that is best for mothers and babies. ${ }^{[9]}$

This study aims to analyze the impact of intensive care of the puerperium (ICP) on the ability of postpartum selfcare in Wonokromo Village, East Java.

\section{Methods}

This study used quasi-experimental research design in the form of nonequivalent control group design with a quantitative study approach on puerperium intensive care variables (intervention was given to an experimental group of 37 respondents, and 37 other respondents were not given intervention but still get the same health services as given to postpartum mothers). Furthermore, data of postpartum self-care being collected using qualitative methods (interview) from 74 respondents.

The population of postpartum mothers with nonprobability sampling technique with incidental sampling for three months, from April to June 2019 in Wonokromo Village, Surabaya with a sample size of 74 respondents, data were analyzed using the chi-square test.

\section{Results and Discussion}

Table 1Frequency distribution of respondent

\begin{tabular}{llcc}
\multicolumn{4}{c}{ characteristics } \\
\hline No & Characteristics & f & \% \\
\hline 1 & Parity & & \\
& Primipara & 26 & 35,1 \\
& Multipara & 48 & 64,9 \\
\hline 2 & Age & & \\
& $20-35$ & 65 & 87,8 \\
& $<20$ or $>35$ & 9 & 12,2 \\
\hline
\end{tabular}

Table 1 shows that from 74 respondents, $64.9 \%$ were nullipara. From 74 respondents, almost entirely $(87.8 \%)$ are aged 20 to 35 years.

Puerperium intensive care (ICP) was carried out after the fourth stage of labour ends with early mobilization; where respondents were guided right and 
left-leaning, sitting, standing, and walking. The uterine involution process will generally proceed if the mother was willing to mobilize early. Early mobilization (early ambulation) is a policy to guide the postpartum mother to get up from her bed and guide as quickly as possible to get back on track ${ }^{[7]}$.The benefits of early mobilization are to facilitate circulation in the mother's body so that it helps the process of involution ${ }^{[8]}$.

In addition to early mobilization, a relaxation massage on head and oxytocin massage could make the mother feel comfortable and stimulate the release of the hormone oxytocin. The hormone oxytocin is useful for regulating and strengthening uterine contractions, compressing blood vessels, and helping postpartum maternal haemostasis, thereby reducing the incidence of bleeding due to uterine atony. Uterine contract strongly will result in a better involution process ${ }^{[9]}$.

Proper breast care and breastfeeding techniques can help mothers to expedite milk production. Breast excercise was done to keep the breasts posture. Another effort in expediting involution was postpartum excercise starting from the first day of postpartum to 10 days of postpartum by putting forward maternal care. Counselling during the puerperium was essential to preparing the mother to maintain their health and early detection of complications in the puerperium period. This counselling covers the basic needs of the puerperal mother as well as signs of danger during the puerperium.

Maternal needs during puerperium are nutrition and fluids, elimination, ambulation, rest, family planning, sexual, personal hygiene and perineum, and postpartum exercises ${ }^{[10]}$. Therefore counselling significantly affects the mother in carrying out the puerperium period.

$\begin{array}{cclc}\text { Table } 2 & \begin{array}{l}\text { Frequency distribution } \\ \text { respondents } \\ \text { postpartum self-care }\end{array} & \begin{array}{c}\text { of } \\ \text { on }\end{array} \\ & & \end{array}$

\begin{tabular}{lccc}
\hline No & Sef-Care & F & \% \\
\hline 1 & Properly & 34 & 45,9 \\
\hline 2 & Improperly & 40 & 54,1 \\
\hline Jumlah & 74 & 100 \\
\hline
\end{tabular}

Table 2 shows that from 74 respondents, $54.1 \%$ were lacking in doing self-care.

Many factors affected the lack of postpartum self-care both internally (originating from themself) and external factors (originating from outside). One of the internal factors was parity; most of the respondents in this study were multipara. Multipara is a woman who has given birth to a child more than once. ${ }^{[1]} \mathrm{A}$ mother who has given birth will have experience from the previous time, meaning that it will be a proper provision in undergoing the current puerperium and is expected to be better. It showed that most of the respondents were multipara, bu their selfcare was lacking. Their previous experience was insignificant for the current period.

Another internal factor was age. Almost all respondents $(87.8 \%)$ were aged 20-35 years. It is a reproductive age where the respondents still have their opportunity in pregnancy so that the role of ICP in postpartum care is beneficiary. The age of 20-35 years is an age that is still very productive and active so that mothers have high motivation to care for themselves.

Based on the data on postpartum self-care, many mothers did not exercise regularly with various reasons such as still feeling pain in their stitches, busy taking care their household, forget, and some say that they feel good without exercise. On the other hand, many mothers said they understood the benefits of puerperal exercise, but they remained irregular even did not do puerperal exercises.

In addition to postpartum exercise, self-care was done by the respondents most lacking was breast care. Postpartum mothers had received counselling about breast care, but often forget the steps that must be done or doing breast care improperly. Using supporting bras and 
adequate rest is also necessary. Breast care was done to keep the breast clean and dry. ${ }^{[12]}$

Table 3 Cross-tabulation of intensive carepuerperium effect on the ability of postpartum self-care

\begin{tabular}{|c|c|c|c|}
\hline \multirow{2}{*}{$\mathrm{ICP}$} & \multicolumn{2}{|c|}{ Postpartum self-care } & \multirow[b]{2}{*}{$\begin{array}{l}\text { Total } \\
(\%)\end{array}$} \\
\hline & $\begin{array}{l}\text { Properly } \\
(\%)\end{array}$ & $\begin{array}{c}\text { Improperly } \\
(\%)\end{array}$ & \\
\hline Yes & $\begin{array}{l}23 \\
(62.2)\end{array}$ & $14(37.8)$ & $\begin{array}{l}37 \\
(100)\end{array}$ \\
\hline No & $\begin{array}{l}11 \\
(29.7)\end{array}$ & $26(70.3)$ & $\begin{array}{l}37 \\
(100)\end{array}$ \\
\hline Total & $\begin{array}{l}34 \\
(45.9)\end{array}$ & $40(54.1)$ & $74(100)$ \\
\hline
\end{tabular}

Table 3 shows that from 37 respondents who were given ICP, $62.2 \%$ of respondents doing postpartum self-care

The ICP carried out on 37 respondents had a significant impact on the physical and psychological state of respondents. Physically their body was fresher; breasts were not swollen, lochea flows smoothly, and recover sooner. Psychologically, they feel happy because it is not only health workers who accompany her, but her husband and family, as well as cadres also pay attention to them by facilitating their needs in accordance to achieve their ability to self-care. The support of health workers and families gives a remarkable impact on psychological of postpartum mothers, while the act of self-care will impact on physiological. These physiological include the reproductive system, circulatory system, urinary system, musculoskeletal system, hormonal and endocrine changes, gastrointestinal system, abdomen, body weight, lactation or breast, and integumentary system ${ }^{[12]}$. The existence of these changes indicates that intensive care for postpartum mothers is indeed needed.

\section{Conclusion}

Most respondents (62.16\%) received intensive care puerperium (ICP) were capable of performing postpartum selfcare properly. Respondents who did not properly, and from 37 respondents who were not given ICP, $70.3 \%$ of respondents had postpartum self-care lacking.

Statistically show that the $\mathrm{p}$-value $=0.005$ it means that there was an effect of ICP on the ability of postpartum selfcare.

ICP give a positive impact in order to improve the mother's ability in self-care. It was known from the recapitulation of the data; the respondents did all the guidance given to them, although some respondents had hesitated to do so for various reasons, like not having time. Many respondents stated that they feel more relaxed, calm, comfortable, and happy after doing self-care. This conditions will have a positive impact on the sustainability of maternal health so that it is maintained.

receive ICP, mostly (70.27\%) were lacking in doing postpartum self-care.

There was a significant impact on Intensive Care Puerperium (ICP) on the ability of postpartum self-care. A similar study is needed to examine psychological responses to the application of ICP to enhance this study

\section{Reference}

[1] Kemenkes RI. Profil Kesehatan Indonesia 2016. Jakarta. Kementerian Kesehatan Republik Indonesia. 2017. http://www.depkes.go.id/resourc es/download/pusdatin/profilkesehatan-indonesia/ProfilKesehatan-Indonesia-2016.pdf (diakses 19 Juli 2019)

[2] World Health Organization. Trends in Maternal Mortality: 1990 to 2015. Geneva: WHO, UNICEF. UNFPA, and The World Bank. 2015.https://www.afro.who.int/si tes/default/files/2017-05/trendsin-maternal-mortality-1990-to2015.pdf (diakses 11 Desember 2019)

[3] Bobak, L. Buku Ajar Keperawatan Maternitas. IV. Jakarta. 2004. 
[4] Fathurrohman, dkk.Gambaran Kondisi Fisik Ibu Pada Hari Ketiga Postpartum Setelah Diberikan Reminder Tentang Perawatan Postpartum Melalui SMS Di Ruang Dahlia RSUD Sumedang. Student e-journals, 1(1). 2012.

[5] Reeder, S.J., et al. Keperawatan Maternitas: Kesehatan Wanita, Bayi dan Keluarga. 2011. Edisi 18, volume 2. Jakarta: EGC

[6] Sulistyawati, A. Buku ajar asuhan kebidanan pada ibu nifas. Yogyakarta: Andi Offset. hlm. 16; 74-86. 2009.

[7] Yanti, D dan Sundawati, D. Asuhan kebidanan masa nifas belajar menjadi bidan profesional. Bandung: Refika aditama. 2011.

[8] Saleha, Sitti. Asuhan kebidanan pada masa nifas. Jakarta: Salemba Medika. 2009.

[9] Suherni, et al. Perawatan masa nifas. Yogyakarta: Fitramaya. 2009.

[10] Cuningham.Obsietri Williams. Edisi 21.Volume 1. Jakarta: EGC. 2006.

[11] Dewi, V dan Sunarsih, T. Asuhan Kebidanan Pada Ibu Nifas. Jakarta: Salemba Medika. 2011.

[12] Prawirohardjo, Sarwono. Buku Acuan Nasional Pelayanan Kesehatan Maternal Dan Neonatal.Jakarta: PT Bina Pustaka Sarwono Prawirohardjo. 2010 